Ostroverkhov M., Trinchuk $\mathbf{D}$.

\title{
THE DEVELOPMENT OF THE MATHEMATICAL MODEL OF \\ A NONLINEAR ELECTRICAL CIRCUIT WITH AN INDEPENDENT CONTROLLABLE ELECTROMECHANICAL ENERGY CONVERTER
}

Об’єктом даного дослідження є нелінійне електричне коло з автономним регульованим електромеханічним перетворювачем енергіі. Таке коло на съогоднішній день має широке практичне застосування в різних транспортних засобах, розробники яких проводять дослідження та розрахунок таких кіл на всіх етапах проектування.

Одним з проблемних місиь такого кола є складність його розрахунку. Коло містить ряд нелінійних фізичних елементів: електродвигун, акумулятор, суперконденсатор. Числові розрахунки такого кола будуть дуже складними та вимагають великої обчислювальної потужності. Як наслідок, багато існуючих моделей для дослідження таких кіл є сильно спрощеними, що не дає можливості здійснювати точні енергетичні розрахунки.

В ході даного дослідження була створена математична модель даного кола, адекватність якої достатня для енергетичних розрахунків при мінімальній складності. Для цього були досліджені існуючі моделі елементів кола, в яких було знехтувано параметрами з несуттєвим впливом на електромагнітні процеси. При цьому короткочасні ефекти, такі як імпульсний характер перетворення електричної енергї та додаткові втрати енергї в елементах, були враховані. На основі математичної моделі створена комп'ютерна модель нелінійного електричного кола з автономним регульованим електромеханічним перетворювачем енергї, яка задовольняє вимоги точності для енергетичних розрахунків та при цьому є помірно складною.

Отримана модель є точнішою для проведення енергетичних розрахунків за більшість існуючих моделей за рахунок врахування імпульсних режимів роботи електричного перетворювача та електромагнітних втрат електромеханічного перетворювача. Також завдяки знехтуванню певних параметрів джерела живлення, які незначною мірою впливають на втрати енергї, дана модель має меншу складність, ніж інші точні моделі цього кола. Таким чином, отримана модель буде оптимальною саме для енергетичних розрахунків нелінійного електричного кола з автономним регульованим електромеханічним перетворювачем.

Клочові слова: нелінійне електричне коло, літій-іонний акумулятор, суперконденсатор, асинхронний двигун.

\section{Introduction}

Nonlinear electrical circuits with independent regulated electromechanical energy converters today are widely used. The most common of these is autonomous electric transport: electric cars, electric scooters, electric buses, segways and the like. To improve their competitiveness, it is necessary to improve energy efficiency, including achieving the least possible energy consumption in the dynamics of movement. For this, it is necessary to have a reasonably accurate and at the same time simple model of an electrical circuit for conducting research at the design stage.

Therefore, the actual task is development of a mathematical model that is sufficiently adequate for accurate energy calculations of a nonlinear circle.

\section{The object of research and its technological audit}

The object of research is a nonlinear electric circuit with an independent controllable electromechanical energy converter, which simulates the drive of autonomous electric vehicles. Such a circle contains the following components:
- source of electrical energy - usually lithium-ion batteries, a battery of supercapacitors often being connected in parallel;

- electric energy converter - semiconductor converter with transistors, which provides current parameters on the energy source being equal to current parameters on the consumer;

- electromechanical converter - electric motor.

If, when developing a mathematical model of such an electrical circuit, to take into account all the parameters of its components, then the complexity of the system of mathematical equations not only fails to obtain an analytical solution, but also leads to a high complexity of calculations for its numerical solution. Simplification of the model by neglecting certain parameters can significantly simplify the system of equations while maintaining the required accuracy of calculations.

\section{The aim and objectives of research}

The aim of research is development of a mathematical model of a nonlinear electrical circuit with an independent controllable electromechanical energy converter as 
simple as possible in order to reduce the search time for numerous solutions. But in the same time it should be sufficiently accurate for carrying out energy calculations at the design stage.

To achieve this aim it is necessary to:

1. Create a mathematical model of the real elements of the electrical circuit.

2. Determine which parameters in these models are insignificant enough to be neglected.

3. Complete the development of a mathematical model of the circle, creating a corresponding computer model.

\section{Research of existing solutions of the problem}

To date, a number of studies have been conducted on nonlinear electrical circuits with independent controllable electromechanical energy converters as a whole and their elements separately. For these studies, a number of mathematical models were created with an emphasis on one or another element.

In particular, various mathematical models of asynchronous motors are presented in [1], but without reference to a power source. In the work [2], the most convenient of these models is selected, but it does not take into account the energy losses in the motor magnetic circuit.

In [3], the battery model is presented during its long operation, taking into account its discharge. It also takes into account the voltage drop across the active resistance of the battery, but doesn't take into account the transients occurring in this element. They are shown in $[4,5]$, but without reference to the load.

The study of the battery on the load, including electric motors is presented in [6, 7]. Current trends show that, in addition to the battery, a supercapacitor connected in parallel with it is often used, which was not investigated in one of the above works. The mathematical model of the supercapacitor is given in [8], but without reference to other elements.

A complete electric circuit with a battery, a supercapacitor and a load is investigated in [9]. However, attention is focused solely on the power source, and the load model is very simplified, inadequate to be considered as an electric motor. The motor model is applied in [10], but the control system is simplified to speed up the calculations. Such a model can be sufficiently accurate for dynamic calculations of the electric drive, but it gives a large error in the energy calculations, since it does not take into account the energy processes in the pulse mode with pulse-width modulation.

Thus, the question of creating an adequate model of a nonlinear electrical circuit with an independent controllable electromechanical energy converter for energy calculations remains promising.

\section{Methods of research}

From the point of view of mathematical description, the most difficult element of this circle is the electric motor. The mathematical model for it will differ depending on the type of this motor. The most universal is the description of the induction motor (IM). This is the most common type of motor today; it is very common in electric vehicles. It is also possible to switch from IM models to models of other types of motors.

To reduce the number of equations in the work, the model is considered not in natural three-phase coordinates, but in an orthogonal two-phase coordinate system. Also, for simplicity, we will ignore the loss of energy in the magnetic core of the motor at the moment. The electrical circuit for replacing a single phase of such a system is shown in Fig. 1, where indicated:

$R_{s}, R_{r}$ - active resistances of stator and rotor motor windings;

$L_{m}$ - the mutual inductance of the stator and rotor windings;

$L_{l s}, L_{l r}$ - the leakage inductors of the stator and rotor windings, respectively;

$\lambda_{s d}, \lambda_{s q}, \lambda_{r d}, \lambda_{s a}-$ the electromotive force (EMF) of the induction of the stator and rotor windings in projections on the $d$ - and $q$-axes;

$\omega_{e}$ - rotation speed of the magnetic field;

$u_{s d}$ - voltage at the stator winding clamps projected on the $d$-axis.

After mathematical transformations, it is possible to get a complete system of differential equations for IM [2]:

$$
\begin{aligned}
& \left.\begin{array}{cccc}
R_{s}+s L_{s} & -\omega_{e} L_{s} & s L_{m} & -\omega_{e} L_{m} \\
-\omega_{e} L_{s} & R_{s}+s L_{s} & -\omega_{e} L_{m} & s L_{m} \\
s L_{m} & \left(\omega_{e}-\omega_{r}\right) L_{m} & R_{r}+s L_{r} & \left(\omega_{e}-\omega_{r}\right) L_{r} \\
-\left(\omega_{e}-\omega_{r}\right) L_{m} & s L_{m} & -\left(\omega_{e}-\omega_{r}\right) L_{r} & R_{r}+s L_{r}
\end{array}\right]^{-1}\left[\begin{array}{c}
u_{q s} \\
u_{d s} \\
u_{q r} \\
u_{d r}
\end{array}\right], \\
& T_{e}=T_{L}+\frac{2}{p} J \frac{d \omega_{r}}{d t}, \\
& T_{e}=\frac{3}{2}\left(\frac{p}{2}\right)\left(\psi_{d m} i_{q s}-\psi_{q m} i_{d r}\right),
\end{aligned}
$$

where $i_{q s}, i_{q r}, i_{d s}, i_{d r}$ - the currents in the stator and rotor windings in projections onto the $d$ - and $q$-axes; $\omega_{r}$ - rotor speed; $T_{e}$ - the electromechanical torque of the motor; $T_{L}-$ the static torue of the load on the motor shaft; $p$ - the number of pairs of motor poles; $J$ - the reduced moment of inertia of the motor-drive system; $\Psi_{d m}, \Psi_{d m}$ - flux linkages in projections onto the $d$ - and $q$-axes; $s$ - Laplace operator.

This system of equations has a fifth order, but nonlinearity arises in the last equation, which means the system is not to be solved analytically. When creating such a model, the saturation of the magnetic circuit, the non-sinusoidal distribution of the magnetic field, the unevenness of the air gap and the energy loss in the magnetic circuit for hysteresis and eddy currents are rejected.

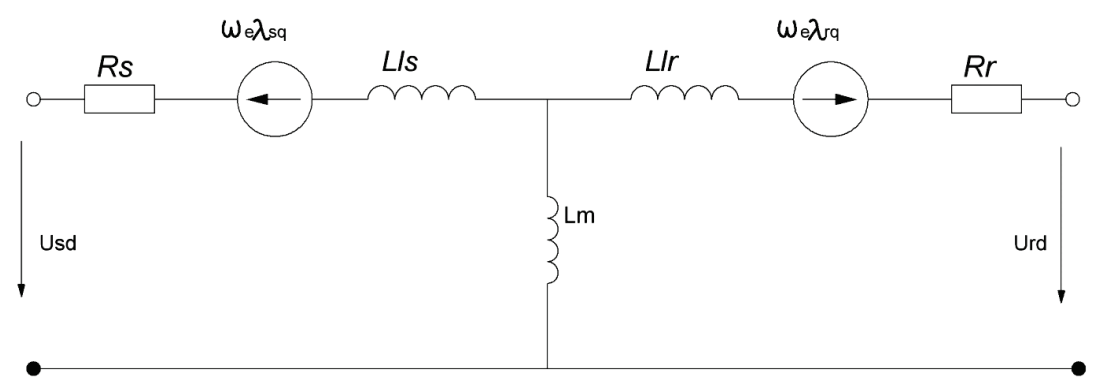

Fig. 1. Equivalent IM replacement circle projected on the $d$-axis 
The latter two are quite significant. In energy calculations, it becomes necessary to take them into account; therefore this will be done later.

The electric circuit of battery replacement is shown in Fig. 2, where it is shown:

$U_{e}$ - battery voltage depending on the state of its charge;

$R_{\text {int }}$ - internal battery resistance;

$C_{L}, R_{L}$ - capacitance and resistance associated with intercalation and mass transfer of lithium;

$C_{H}, R_{H}$ - the electrochemical capacitance and resistance of the double layer;

$U_{n}-$ voltage at the battery output.

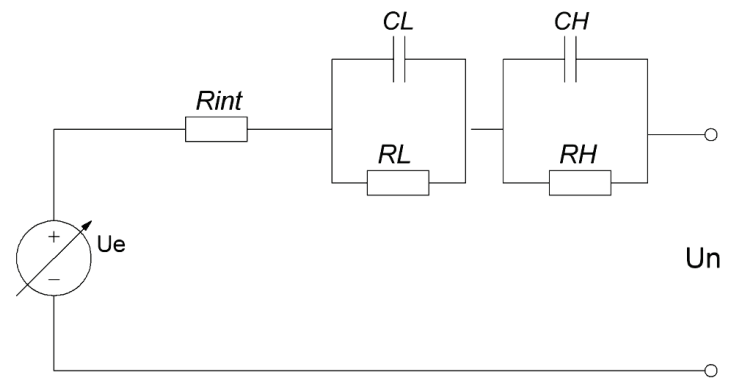

Fig. 2. Equivalent electric circuit of accumulator

In the diagram in Fig. 2 battery voltage is variable and it depends on the state of charge of the battery. This dependence can be expressed with the Shepherd equation [3]:

$$
U_{e}=E_{0}-K\left(\frac{q}{Q-q}\right) i_{e}+A\left(\exp \left(-B \frac{q}{Q}\right)-1\right)
$$

where $E_{0}$ - the battery EMF; $Q$ - maximum battery capacity; $q$ - a full charge, the battery is given while it is working; $i_{e}$ - current through the battery; $K, A, B$ - experimental constants.

Equations derived from this mathematical model also have nonlinearities. However, they can be simplified assuming that calculations at the design stage are carried out for modes that do not exceed dozens of seconds in duration. In this case, with sufficiently high accuracy, it is possible to assume that the state of charge of the battery during this time will not change, and therefore $U_{e}=$ const. In this way, nonlinearity in the battery model can be eliminated. In addition, capacitive circuits in the equivalent circuit can be neglected. Preliminary calculations have shown that their influence on the magnitude of the current will be much weaker than the influence of the electric motor.

For a supercapacitor, there are a number of equivalent circuits. The most common of them is shown in Fig. 3 [9], where it is shown:

$C_{1-3}$ - constant supercapacitor capacity;

$R_{1-3}$ - resistances of capacitive branches of the supercapacitor;

$R_{4}$ - self-discharge resistance;

$C_{V}$ - capacity, the value of which depends on the voltage;

$U$ - voltage on the plates of the supercapacitor.

The diagram in Fig. 3 shows three capacitive branches with different time constants, which grow with an increase in the index number of the branch. Capacity $C_{V}\left(U_{1}\right)$ is a voltage dependent capacity. The dependency function can be taken as linear:

$$
C_{V}=k_{C V}|U|
$$

where $k_{C V}-$ proportionality coefficient, which is determined experimentally.

The mathematical model of the supercapacitor is the following:

$$
\begin{aligned}
& I_{C}=I_{1}+I_{2}+I_{3}+I_{4}, \\
& I_{1}=\left(C_{1}+k_{C V}\left|U_{C}-I_{1} R_{1}\right|\right) \frac{d\left(U_{C}-I_{1} R_{1}\right)}{d t}, \\
& I_{2}=C_{2} \frac{d\left(U_{C}-I_{2} R_{2}\right)}{d t}, I_{3}=C_{3} \frac{d\left(U_{C}-I_{3} R_{3}\right)}{d t}, \\
& I_{4}=\frac{U_{C}}{R_{4}},
\end{aligned}
$$

where $I_{i}$ - the current of the i-th branch of the circuit; $I_{c}-$ the total current flowing through the supercapacitor.

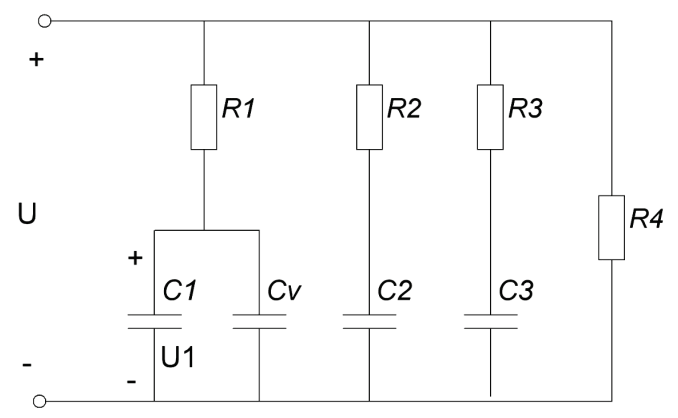

Fig. 3. Supercapacitor equivalent circuit

So, having models of each of the elements, it is possible to draw an equivalent circuit of the electric circuit (Fig. 4), which shows the pulse-width modulator (PWM), which performs the conversion of electrical energy and coordinates the current parameters on the battery and motor.

In addition to the models described above, the circuit has two additional elements: $R_{n}$ and $R_{m}$ are resistances that take into account loads and magnetic losses. Both of these resistances are nonlinear. Load resistance $R_{n}$ can be determined from the mechanical power of the load:

$$
P_{2}=\frac{U_{2}^{2}}{R_{n}}, R_{n}=\frac{U_{2}^{2}}{P_{2}},
$$

where $P_{2}$ - the mechanical power, which is set by the load characteristic for the desired modes of operation; $U_{2}-$ the voltage at the output of the equivalent circuit of the motor, which can be determined from system (1).

The expression for determining the resistance value $R_{m}$ is found from the equality of the power of the electric losses on the support and the power of the magnetic losses in the motor and has the following form:

$$
\frac{U_{1}^{2}}{R_{m}}=k_{m} \psi^{2} f^{1,5}, R_{m}=\frac{U_{1}^{2}}{k_{m} \psi^{2} f^{1,5}},
$$

where $U_{1}$ - the voltage at the PWM input; $\Psi$ - magnetic flux, which is defined by space-vector control; $f$ - the frequency of the current in the AM circuit, which is set by space-vector control; $k_{m}$ - proportionality coefficient, which is determined experimentally. 


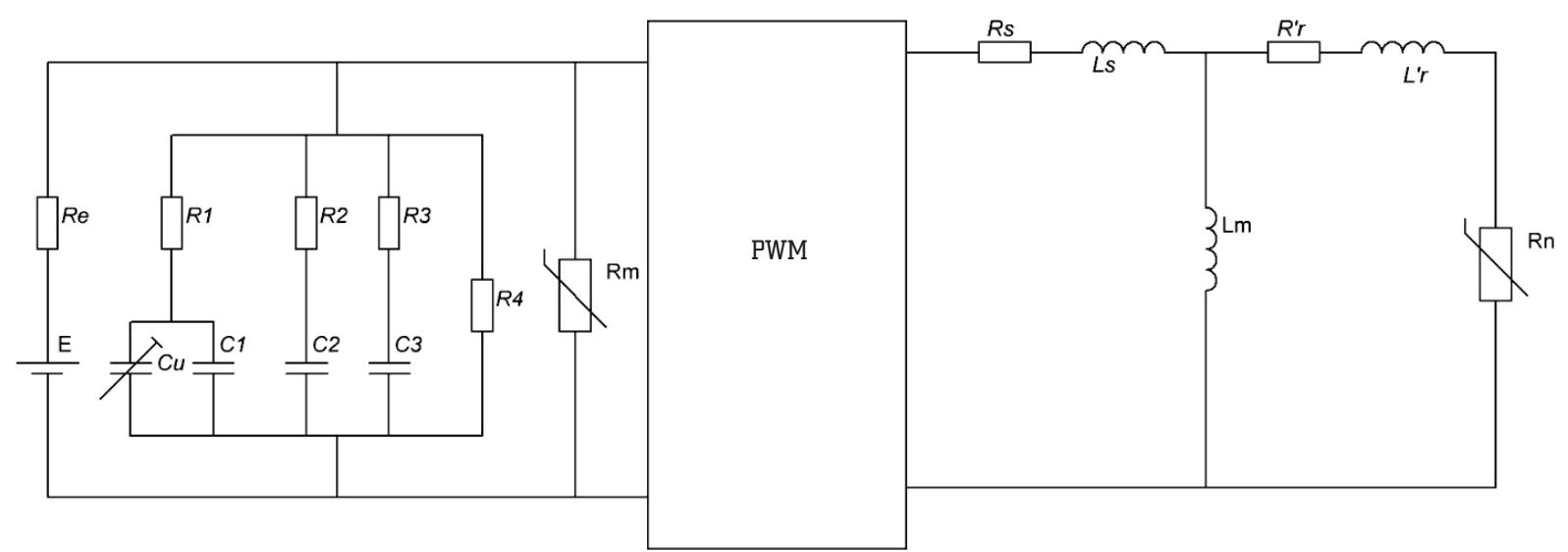

Fig. 4. Simplified equivalent electrical circuit: PWM - pulse-width modulator

\section{Research results}

The resulting system of mathematical equations contains four nonlinearities: the products of flow coupling and currents in an induction motor, nonlinear capacitance of supercapacitors and nonlinear resistors $R_{m}$ and $R_{n}$. Therefore, to solve such a system, it becomes necessary to apply numerical calculations. For this purpose, a computer model of this circle is developed in the Matlab Simulink software package (Fig. 5).

This model allows with sufficient accuracy to conduct research and calculations of the parameters of the circle at the design stage. As a motor load, the user can specify either a constant moment of resistance, or a moment proportional to the square of the speed (fan characteristic), or their sum. The control of the electromechanical converter is performed according to the laws of spacevector control by setting the speed of rotation of the motor rotor and magnetic flux. The study of the model shows the adequacy of electromagnetic processes in the developed equivalent electric circuit to processes in a real circle with an independent controllable electromechanical converter.

\section{SWOT analysis of research results}

Strengths. In the course of the research, mathematical and computer models of a nonlinear electric circuit with an independent controllable electromechanical energy converter were developed. In contrast to the already existing models, this model helps to carry out more accurate calculations of the energy processes and efficiency of the circle, taking into account the pulsed modes of operation created by the pulse-width modulator. It also takes into account the loss in the magnetic circuit of the motor for hysteresis and eddy currents. Due to this, when using the model for calculations at the design stage, it is possible to choose more rational parameters of the circuit elements to improve its efficiency.

Weaknesses. The model is due to accuracy and, as a result, complexity, more cumbersome for assessing the dynamic performance of an electrical circuit with an adjustable electromechanical converter, because simpler existing models allow this to be done at much lower computational costs.

Opportunities. The model is developed with taking into account electromagnetic processes in the circle of the most common induction electric motor. The development of a similar model taking into account electromagnetic processes in other types of motors, in particular, step motors and synchronous motors with permanent magnets, is promising.

Threats. The model is not confirmed experimentally at full strength. The adequacy of only the basic elements is experimentally confirmed; therefore, for carrying out calibration experiments, it can't be considered reliable.

\section{Conclusions}

1. A mathematical model of a nonlinear electrical circuit with an independent controllable electromechanical energy 
converter is created. The model is designed to meet the accuracy requirements required for energy calculations.

When developing a circle model, the existing mathematical models of individual elements of the real circle were investigated: an induction motor, a lithium-ion battery and a supercapacitor, and on the basis of them the most optimal models for these elements in this circuit were compiled.

2. During the analysis of these models, it is found that to speed up the calculations it is possible to simplify the accumulator battery model, while the motor model is not accurate enough because it did not take into account the losses in the magnetic circuit. These losses are taken into account in the equivalent circle model by including a nonlinear resistor in it.

3. Based on the mathematical model in the Matlab Simulink software package, a computer model of this circle is developed. The model allows conducting research and calculations of a circle with an accuracy sufficient to determine its energy characteristics at moderate computational costs.

\section{References}

1. Pankratov V. V. Vektornoe upravlenie asinkhronnym elektroprivodom. Novosibirs'k, 1999. 66 p.

2. Stat'i o vektornom upravlenii. URL: http://xn----8sbecmada0aoptggbsmf4a0a.xn--p1ai/stati-o-vektornom-upravlenii.html

3. Shepherd C. M. Design of Primary and Secondary Cells Journal of The Electrochemical Society. 1965. Vol. 112, Issue 7. P. 657-664. doi: http://doi.org/10.1149/1.2423659

4. Tang X. Li-ion battery parameter estimation for state of charge // American Control Conference (ACC). 2011. P. 941-946. doi: http://doi.org/10.1109/acc.2011.5990963
5. Wang C., Appleby A. J., Little F. E. Electrochemical impedance study of initial lithium ion intercalation into graphite powders Electrochimica Acta. 2001. Vol. 46, Issue 12. P. 1793-1813. doi: http://doi.org/10.1016/s0013-4686(00)00782-9

6. Battery Management System: An Overview of Its Application in the Smart Grid and Electric Vehicles / Rahimi-Eichi H. et. al. // IEEE Industrial Electronics Magazine. 2013. Vol. 7, Issue 2. P. 4-16. doi: http://doi.org/10.1109/mie.2013.2250351

7. Lee J., Nam O., Cho B. H. Li-ion battery SOC estimation method based on the reduced order extended Kalman filtering // Journal of Power Sources. 2007. Vol. 174, Issue 1. P. 9-15 doi: http://doi.org/10.1016/j.jpowsour.2007.03.072

8. Matching the nanoporous carbon electrodes and organic electrolytes in double layer capacitors / Maletin Y. et. al. // Applied Physics A. 2005. Vol. 82, Issue 4. P. 653-657. doi: http://doi.org/ 10.1007/s00339-005-3416-9

9. Biletskyi O. O. Enerhetychni protsesy v kolakh zariadu superkondensatoriv zi zminnymy pochatkovymy napruhamy: $\mathrm{PhD}$ thesis. Kyiv, 2016. 195 p.

10. A MPC based energy management strategy for battery-supercapacitor combined energy storage system of HEV / Liu S. et. al. // 35th Chinese Control Conference. 2016. P. 8727-8731. doi: http://doi.org/10.1109/chicc.2016.7554751

Ostroverkhov Mykola, Doctor of Technical Sciences, Professor Head of Department of Theoretical Electrical Engineering, National Technical University of Ukraine «Igor Sikorsky Kyiv Polytechnic Institute», Ukraine, ORCID: http://orcid.org/0000-0002-7322-8052, e-mail: n.ostroverkhov@hotmail.com

Trinchuk Danylo, Postgraduate Student, Department of Theoretical Electrical Engineering, National Technical University of Ukraine «Igor Sikorsky Kyiv Polytechnic Institute», Ukraine, ORCID: http://orcid.org/ 0000-0001-6022-9323,e-mail:d.trinchuk@gmail.com 